\title{
Islet cell and other organ-specific autoantibodies in all children developing Type 1 (insulin-dependent) diabetes mellitus in Sweden during one year and in matched control children
}

\author{
M. Landin-Olsson ${ }^{1}$, A. Karlsson ${ }^{2}$, G. Dahlquist ${ }^{3}$, L. Blom ${ }^{3}$, Å. Lernmark ${ }^{1}$, G. Sundkvist ${ }^{1}$ and co-workers* \\ ${ }^{1}$ Department of Medicine, University of Lund, Malmö General Hospital, ${ }^{2}$ Department of Medicine, University of Uppsala, and \\ ${ }^{3}$ Department of Paediatrics, Karolinska Institute, Sachs' Children's Hospital, Stockholm, Sweden
}

Summary. The majority (about $90 \%$ ) of children developing Type 1 (insulin-dependent) diabetes mellitus do not have a first-degree relative with the disease. Nearly all $(389 / 405$, 96\%) children (0-14 years) in Sweden, who developed diabetes during one year, were therefore studied to compare islet cell, thyroid peroxidase, thyroglobulin, and gastric $\mathrm{H}^{+}$, $\mathrm{K}^{+}$-ATPase antibodies with 321 age, sex, and geographically matched, but non-related, control children. Islet cell (cytoplasmic) antibodies were found in $81 \%(316 / 389)$ of the patients and in $3 \%(9 / 321)$ of the control children $(p<0.001)$. The median islet cell antibody levels were 70 (range 3-8200) Juvenile Diabetes Foundation (JDF) Units in the islet cell antibody positive patients, and 27 (range 17-1200) JDF Units in the control children (NS). Autoantibodies against thyroid peroxidase $(8 \%)$, thyroglobulin $(6 \%)$, and gastric $\mathrm{H}^{+}, \mathrm{K}^{+}$ATPase $(3 \%)$ were all increased in the patients compared with the control children, being $2 \%(p<0.001), 2 \%(p<0.01)$, and $0.3 \%(p<0.01)$, respectively. During an observation time of 20-34 months, two of the nine islet cell antibody positive con- trol children developed Type 1 diabetes, after 8 and 25 months respectively, while the others remained healthy and became islet cell antibody negative. None of the islet cell antibody negative control children developed diabetes during the same time of observation. This first investigation of an unselected population of diabetic children and matched control children shows: that islet cell antibodies are strongly associated with newly diagnosed childhood diabetes, that other autoantibodies are more frequent among diabetic children than control children, and that the frequency of islet cell antibodies in the background population of children is higher than previously documented, and could also be transient, underlining that factors additional to islet cell antibodies are necessary for the later development of Type 1 diabetes.

Key words: Type 1 (insulin-dependent) diabetes mellitus, islet cell antibodies, thyroid peroxidase antibodies, thyroglobulin antibodies, $\mathrm{H}^{+}, \mathrm{K}^{+}$-ATPase antibodies, case-control study.
Type 1 (insulin-dependent) diabetes mellitus is the most frequent chronic disease among children in developed countries [1-3] and is associated with a markedly increased mortality $[4,5]$. Insulin treatment remains a substitution therapy, and a cure or prevention for Type 1 diabetes remains to be found, further stressed by the observation that the incidence of Type 1 diabetes in children seems to be increasing in several countries [6-9]. Geographical differences [6], seasonal variation [10,11], and a low concordance rate in identical twins $[12,13]$ suggest that virus infections [14-17] or other environmental factors [18-19] may be of importance in the aetiology.

Several autoimmune phenomena related to the endocrine pancreas and of possible pathogenetic importance are detected at the clinical onset of Type 1

* The names of the co-workers are listed in the Acknowledgement section diabetes [20-22]. Insulitis may be detected at, or shortly after, the clinical diagnosis [23-25] and there is a specific loss of islet B cells [26]. Moreover, islet cell (cytoplasmic) antibodies (ICA) [27, 28], islet cell surface antibodies [29], cytotoxic islet cell antibodies [30, 31], autoantibodies against an islet cell protein of $\mathrm{M}_{\mathrm{r}} 64,000$ $[32,33]$, and insulin autoantibodies [34] are common before, or at, the clinical onset $[33,35,36]$. In addition, Type 1 diabetic patients have an increased risk of developing other organ-specific autoimmune disorders perhaps representing a separate syndrome of polyendocrinopathy $[37,38]$. The levels of ICA in newly diagnosed diabetic children [39-45] and the frequency of ICA in control children [39-49] have been variable and contradictory.

In the present study we had the unique opportunity to analyse ICA and other organ-specific autoantibodies in a nearly complete $(389 / 405,96 \%)$, one year population of newly diagnosed Type 1 diabetic children 
Table 1. Autoantibodies in a total annual population of newly diagnosed children with Type 1 (insulin-dependent) diabetes mellitus and matched control children

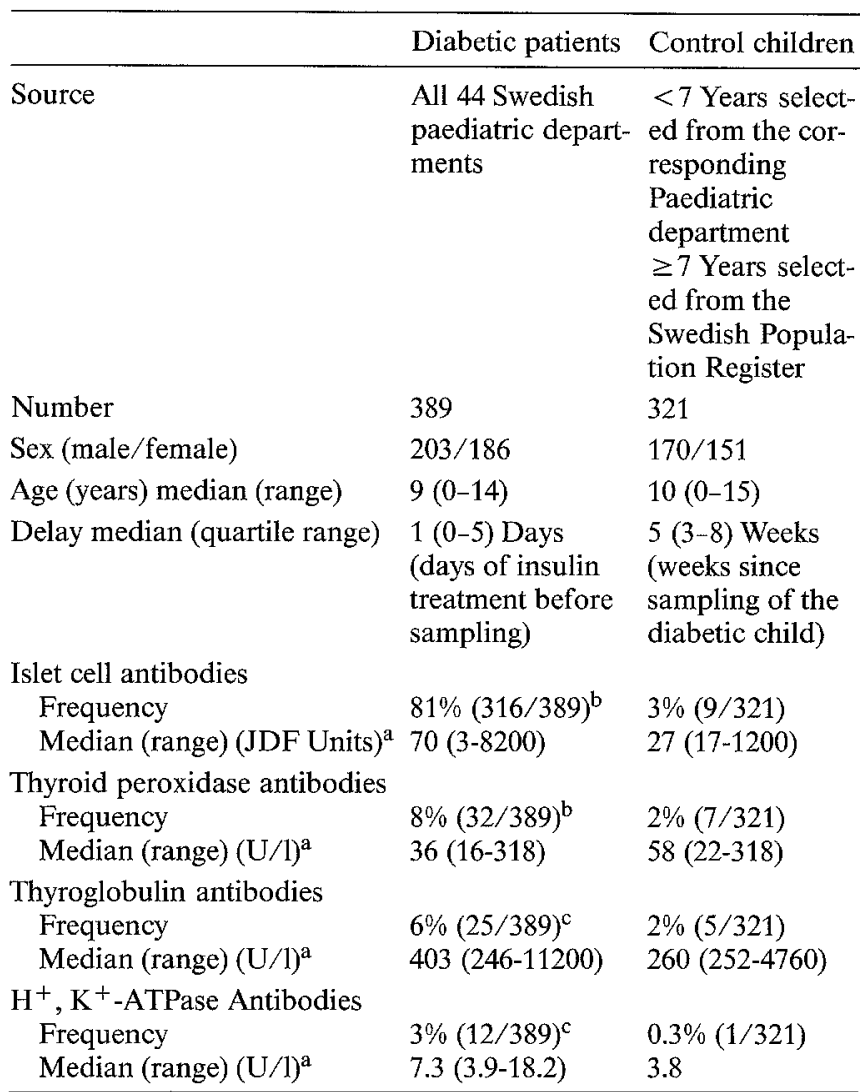

a Only positive values are taken into account; ${ }^{\mathrm{b}} p<0.001$ vs control children; ${ }^{\mathrm{c}} p<0.01$ vs control children

country wide, together with age, sex, and geographically matched control children. Standardized assays for autoantibodies against islet cell, thyroid peroxidase (thyroid microsomal antibodies), thyroglobulin, and gastric $\mathrm{H}^{+}, \mathrm{K}^{+}$-ATPase (parietal cell antibodies) were used to answer the following questions: What are the frequencies and levels of ICA and other organ-specific autoantibodies? Are there any associations between these antibodies? Are the autoantibodies influenced by age, sex, season, or geographic location at diagnosis of Type 1 diabetes? Are the autoantibodies associated with heredity of Type 1 diabetes or heredity of other diseases? What are the frequencies and levels of islet cell and other autoantibodies in control children matched for age, sex, and geographical location?

\section{Subjects and methods}

\section{Patients}

Sweden has 8.4 million inhabitants and 1.6 million of them are children 0-14 years of age. In accordance with the Swedish Health Care programme for diabetic children, all children who develop Type 1 diabetes are admitted to one of the 44 Paediatric departments. These departments are all members of the Swedish Childhood Diabetes Register where all new cases of Type 1 diabetes in children up to 15 years of age are reported [6]. The present study comprised 96\% (389/405) of all children 0-14 years of age in Sweden with Type 1 diabetes diagnosed between September 1, 1985-August 31, 1986 (Table 1). The missing samples were mainly due to technical reasons. The patients were 3 months -14 years of age (median 9 years), the sex ratio was 1.1 ( 203 boys and 186 girls), and the median time from insulin treatment to the serum sampling was 1 day (quartile range $0-5$ days) (Table 1 ). Information of heredity was obtained from questionnaires completed on $85 \%(332 / 389)$ of the Type 1 diabetic children.

\section{Control children}

The Swedish Ethical Committee did not allow serum sampling exclusively for research purposes from children younger than 7 years of age, and because of this control children to patients younger than 7 years old $(n=132)$ were selected from children hospitalized for reasons other than diabetes in the same hospital as the corresponding diabetic patient. The hospital control children $(n=98)$ had been admitted for elective surgery $(30 \%)$, elective investigation and X-ray (usually pyelography) (27\%), observation (18\%), trauma (3\%), and unspecified or missing diagnosis $(22 \%)$. They were selected as not having Type 1 diabetes or any indication of other endocrine diseases. For patients aged seven years or older $(n=257)$ two control children were selected from the Swedish Population Register, identified by their civic registration numbers, and matched to the Type 1 diabetic children with respect to age (born on the same day), sex, and residence (living in the same county) as described in detail [50]. Among the 514 invited control children, 223 (43\%) agreed to participate and donate a serum sample. The total group of control children, therefore, consisted of 321 children (Table 1). The sex ratio was 1.1 (170 boys and 151 girls) and the median age at sampling was 10 years (range 3 months15 years). The median time between serum sampling from the Type 1 diabetic patient to the control child was 5 weeks (quartile range 3-8 weeks) (Table 1). Information of heredity was available from the completed questionnaires of $98 \%(219 / 223)$ of the control children aged 7 years and older. For the younger control children information of heredity was obtained from $60 \%(59 / 98)$.

The local paediatrician examined the ICA positive control children and obtained additional fasting samples for determination of blood glucose, $\mathrm{HbA}_{1} \mathrm{c}$, and serum C-peptide [51]. The whole population of control children was later matched against the up-dated Diabetes Register to search for diabetes development among the control children, giving a follow-up time of 20-34 months.

Informed consent was obtained from all patients, control children, and their parents. The specific purpose of the study was not revealed. The study was approved by the the Swedish Ethical Committee, and the Swedish Data Inspection Board.

\section{Collection of sera}

Venous blood samples were obtained from all children except two control children in whom capillary blood was taken. The blood samples were centrifuged, serum was transferred to a new tube at the local hospital, and sent unfrozen by express mail to the Department of Medicine, Malmö General Hospital. The mailing time was 1-3 days from all parts of Sweden. On arrival, sera were aliquoted and first stored for up to one week at $-20^{\circ} \mathrm{C}$ and thereafter, at $-80^{\circ} \mathrm{C}$ until analysis 1-6 months later.

\section{Islet cell cytoplasmic antibodies}

One unfixed, frozen pancreas from a human cadaver organ donor of blood group 0 was used in our indirect two-colour immunofluorescence assay $[52,53]$. Briefly, $1-3 \mu \mathrm{m}$ sections were allowed to dry on 
slides. In a first incubation, $25 \mu 1$ serum diluted in phosphate buffered saline (PBS) containing a monoclonal proinsulin antibody GS9A8 [54] and $0.5 \mathrm{mg} / \mathrm{ml}$ aprotinin (Trasylol, Bayer AG, Leverkusen, FRG) to prevent proteolysis [55] was added to each section. After incubation for $18 \mathrm{~h}$ in a dark, moist chamber, the slides were washed, and then incubated with $25 \mu$ l of a mixture of two fluorescent second antibodies; one being a Texas red-labelled sheep anti-mouse $\operatorname{IgG}(\mathbf{N} 2031$, Amersham, Buckinghamshire, UK) to visualize the mouse monoclonal proinsulin antibody, and the other fluoresceine isothiocyanate (FITC) conjugated rabbit anti-human IgG (Code F 202, Dako, Copenhagen, Denmark) to detect ICA. Coded slides were washed, mounted in Tris $\mathrm{HCl}(\mathrm{pH} \mathrm{8.4)} \mathrm{containing} \mathrm{30 \%} \mathrm{glycerol} \mathrm{and} \mathrm{evaluated} \mathrm{in} \mathrm{a} \mathrm{fluores-}$ cence microscope with epiillumination (Olympus BH 2) by at least two independent observers. The observers agreed in $93 \%$.

Sera were diluted 1:2,1:4, 1:8, etc., until end point titre. All sera were tested in at least two separate assays. Sera from ICA positive control children were tested repeatedly after the code was broken. The end point titres are expressed in Juvenile Diabetes Foundation (JDF) Units [56] obtained by the construction of a standard curve as a linear regression line between multiple end point titres of different dilutions of an international reference serum [56]. The two-colour assay allowed us to clearly distinguish between the ICA fluorescence reaction covering $B$ cells and other islet cells. In each assay, one ICA positive internal standard sample in five different dilutions and one negative sample in three dilutions were included as assay quality controls. The interassay variation was 0.9 titration steps estimated from the standard deviation of the positive standard sera.

\section{Thyroid antibodies}

Antibodies against thyroid peroxidase (TPO) and thyroglobulin (TG) were determined in enzyme-linked immunosorbent assays (Pharmacia, Uppsala, Sweden). Purified human TPO [57] and purified human TG were used for coating. Sera were diluted 1: 1000 in PBS containing $0.5 \%$ Tween-20 and incubated in duplicate wells. Bound antibodies were detected with $\beta$-galactosidase-conjugated rabbit anti-human IgG and substrate. Two different patient sera with high titres of TPO antibodies and TG antibodies were used as positive controls and for construction of standard curves. The absorbance values obtained with $1: 10,000$ dilution of the reference sera were defined as $100 \mathrm{U} / 1$. The upper normal limits, determined as the means +2 SD of the data obtained with the sera from the control children of the study, were $15 \mathrm{U} / 1$ for TPO antibodies and $245 \mathrm{U} / 1$ for TG antibodies, respectively.

\section{Gastric $H^{+}, K^{+}$-ATPase antibodies}

The autoantigen which detects parietal cell autoantibodies, $\mathrm{H}^{+}, \mathrm{K}^{+}$ATPase [58], was isolated from porcine stomach and was used for coating wells in an enzyme-linked immunosorbent assay as recently described [59]. A patient serum with high titre of $\mathrm{H}^{+}, \mathrm{K}^{+}$-ATPase antibodies was used for constructing standard curves. The absorbance value of a 1:100 dilution was defined as $100 \mathrm{U} / 1$. The upper normal limit, mean +2 SD of values obtained with sera of the control children of this study, was $3.5 \mathrm{U} / 1$.

\section{Statistical analysis}

Values are given as median and quartile range, or mean and standard deviation. Chi square and Fischer's exact test were used to compare frequencies of autoantibodies between patients and control children, with different age groups, sex, season at onset, geographical regions, and heredity of autoimmune diseases. The Sperman rank correlation test was applied when levels of autoantibodies were compared with age and when levels of thyroid autoantibodies were compared with

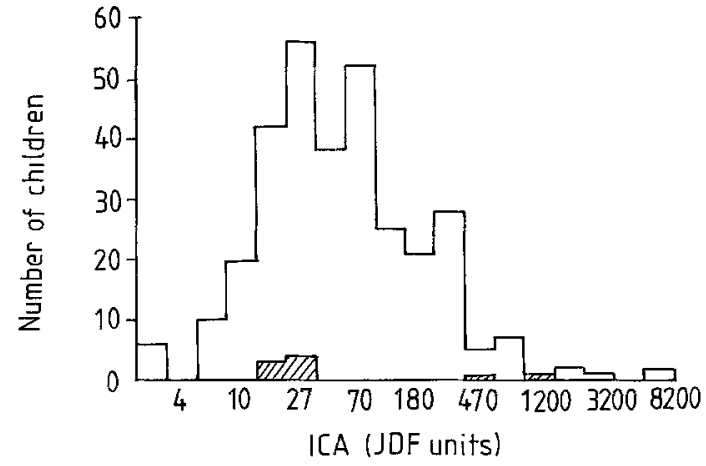

Fig. 1. Distribution of levels (JDF Units) of islet cell antibodies (ICA) in 316 ICA positive patients of a one year population of 389 incident cases of newly diagnosed Type 1 (insulin-dependent) diabetes in Sweden. The ICA levels of nine $(9 / 321,3 \%)$ positive control children are indicated by the dashed columns

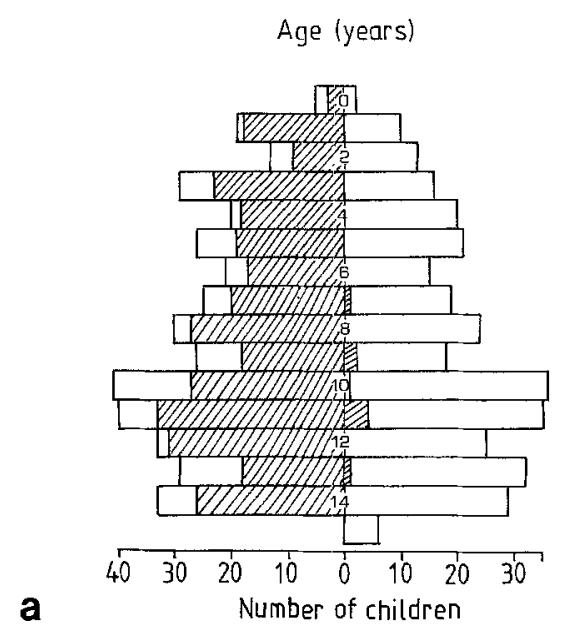

Month of sampling

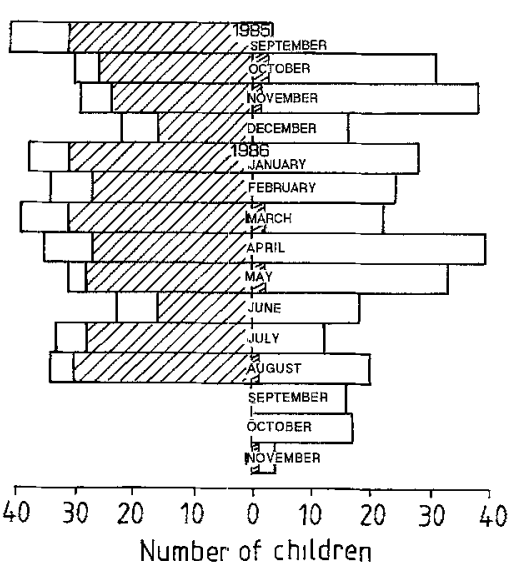

Fig. 2. a Distribution of age at onset in 389 children (left part) who developed Type 1 (insulin-dependent) diabetes mellitus during one year in Sweden. The 321 matched control children are shown to the right. The number of individuals positive for islet cell antibodies are indicated by the dashed columns. b Seasonall distribution shown as month of sampling of 389 children who develloped Type 1 (insulin-dependent) diabetes mellitus (left part) during one year, September 1985-August 1986, and of 321 age, sex, and geographically matched control children (right part). Individuals positive for islet cell antibodies (ICA) are indicated by dashed columns 


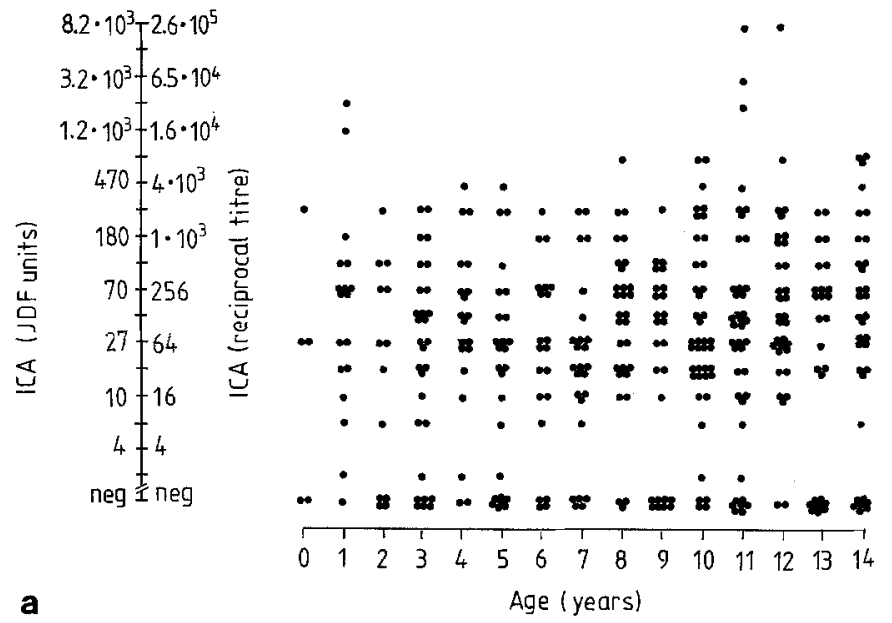

Fig.3. a Relation between the age at onset of Type 1 (insulin-dependent) diabetes mellitus and the individual level of islet cell antibodies (ICA) in 389 children developing Type 1 diabetes during one year in Sweden. b Levels of islet cell antibodies (ICA) in relation to age in the $9 / 321(3 \%)$ control children who were ICA positive. All children were healthy at the time of sampling but those marked by the squares developed Type 1 (insulin-dependent) diabetes mellitus 8 and 25 months later

each other. The Mann-Whitney test was used to evaluate differences between the age distribution in different groups. The logarithm of reciprocal $2 \log$ titres of positive ICA were normally distributed as were the logarithms of TPO, TG, and $\mathrm{H}^{+}, \mathrm{K}^{+}$-ATPase antibodies. An analysis of variance was used to compare levels of antibodies with sex, geographical regions and season at onset. All tests were two-tailed. $P$-value less than 0.05 was considered as a significant difference.

\section{Results}

\section{Frequencies and levels of autoantibodies}

The frequency of ICA among the newly diagnosed Type 1 diabetic children was $81 \%(316 / 839)$, and the median level among ICA positive patient samples was 70 (range 3-8200) JDF Units. In the control group 3\% $(9 / 321)$ were ICA positive and the median level among those was 27 (range 17-1200) JFD Units (Fig.1). The levels of ICA among the patients and control children positive for ICA did not differ significantly.

TPO and TG antibodies were detected in $8 \%$ $(32 / 389)$ and $6 \%(25 / 389)$, respectively, of the Type 1 diabetic patients, demonstrating a significantly higher frequency as compared with the control children where it was $2 \%(7 / 321$ and $5 / 321$, respectively) for the antibodies $(p<0.001$ and $p<0.01$, respectively). In children with thyroid antibodies, the levels of these antibodies were not significantly different between the diabetic patients and control children. Antibodies to the gastric $\mathrm{H}^{+}, \mathrm{K}^{+}$-ATPase occurred significantly more often in the patient group, $3 \%(12 / 389)$ compared with $0.3 \%$ $(1 / 321)$ in the control group $(p<0.01)$ (Table 1$)$.

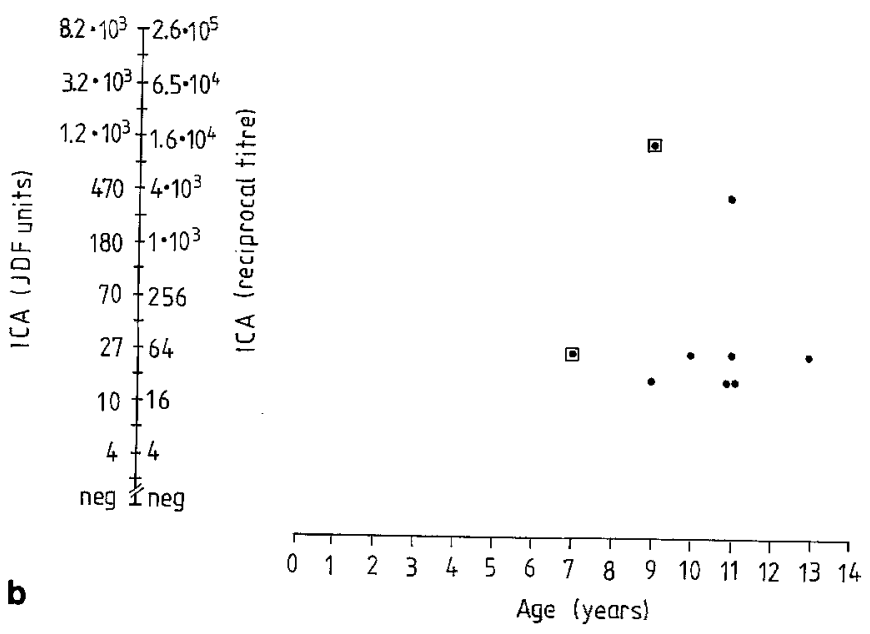

ICA positivity did not correlate with the presence of TPO, TG, or $\mathrm{H}^{+}, \mathrm{K}^{+}$-ATPase antibodies. A strong positive correlation was found between TPO and TG antibodies $\left(r_{\mathrm{s}}=0.87, p<0.001\right) . \mathrm{H}^{+}, \mathrm{K}^{+}$-ATPase antibodies occurred independently of the presence of the thyroid antibodies. Only three $(0.8 \%)$ of the patients were positive for all four autoantibodies and $16(4 \%)$ were positive for three of them. None of the control children were positive for more than two autoantibodies simultaneously.

\section{Effects of age, sex, season and geographic variation}

Neither the frequency (Fig. 2 a) nor the level of ICA (Fig. 3 a) varied with the age of the patient, in fact, the frequency and levels were remarkably stable. However, if only ICA positive patients $(n=316)$ were taken into account the ICA levels tended to increase with increasing age of clinical onset $\left(r_{\mathrm{s}}=0.13, p<0.02\right)$. For ICA there was no difference between males and females, which was found for thyroid antibodies since TPO and TG antibodies were more frequent in female patients with a male/female ratio of $9 / 23$ and $4 / 21$, respectively $(p<0.01$ and $p<0.001)$. The frequency of $\mathrm{H}^{+}, \mathrm{K}^{+}$ATPase antibodies did not vary with age or sex. No difference in frequency (Fig. 2b) or levels of ICA (not shown) were observed when comparing results from patients diagnosed during winter (January-March), spring (April-June), summer (July-September), or autumn (October-December). When frequencies and levels of ICA, TPO, TG, and $\mathrm{H}^{+}, \mathrm{K}^{+}$-ATPase antibodies were compared in the 24 counties, in the six health care regions, or in three latitude regions, no significant geographical differences were observed. Multivariate analyses did not change the results.

\section{Autoantibodies in relation to heredity for Type 1 diabetes and thyroid disease}

Only $8 \%(28 / 332)$ of the newly diagnosed children had a first-degree relative with Type 1 diabetes compared with $1 \%(4 / 278)$ among the control children $(p<0.001)$. 
The frequency and level of ICA among the 28 children with familial Type 1 diabetes $(22 / 28,79 \%$, median 27 JDF Units), did not differ from that of diabetic children without familial diabetes $(250 / 304,82 \%$, median 27 JDF Units). The frequency of thyroid disease among the first degree relatives to the Type 1 diabetic patients was $5 \%$ compared with diseased first degree relatives of the control children which was $3 \%(15 / 332$ vs $6 / 223$, NS). Among the thyroid autoantibody positive diabetic children only one patient had a first degree family member with thyroid disease.

\section{ICA among the control children}

All control children younger than 7 years of age (hospital control children) were ICA negative (Fig. 2a). Among the population based control children who were 7 years or older, there were no children selected by chance who already had Type 1 diabetes. All the nine $(9 / 321)$ ICA positive control children were healthy at the time of sampling, the age range was $7-13$ years (median 11 years) with a sex ratio of 2 ( 6 boys and 3 girls) (Table 2). Two of these children had autoantibodies against islet cells other than $B$ cells, probably against A cells. The median level of ICA among the positive control children was $27 \mathrm{JDF}$ Units (range 17-1200) which was not significantly different from that of the ICA positive Type 1 diabetic children. The presence of ICA positive control children occurred randomly throughout the study year (Fig. 2b) and without any geographical clustering. Two ICA positive control children had fathers with Type 1 diabetes, two had been adopted with unknown heredity, and the remaining five children had no heredity of Type 1 diabetes (Table 2).

Two of the ICA positive control children, a 7-yearold boy and a 9-year-old girl (Fig.3b), developed Type 1 diabetes 8 and 25 months respectively, after their first ICA positive sample. In the samples obtained at diagnosis of Type 1 diabetes ICA were still present in both (Table 2, Fig.4). None of the remaining ICA positive control children have developed diabetes so far, they have all turned ICA negative, and during 20-34 months of observation, fasting blood glucose, $\mathrm{HbA}_{1} \mathrm{c}$, and C-peptide values were normal.

All the initially ICA negative control children $(n=312)$ were checked against the up-dated diabetes register, and during 20-34 months of observation none of these children had developed diabetes.

\section{Discussion}

Factors possibly involved in the aetiology and pathogenesis of Type 1 diabetes are difficult to identify, but will be required in future attempts to screen for children who may later develop diabetes. This investi-

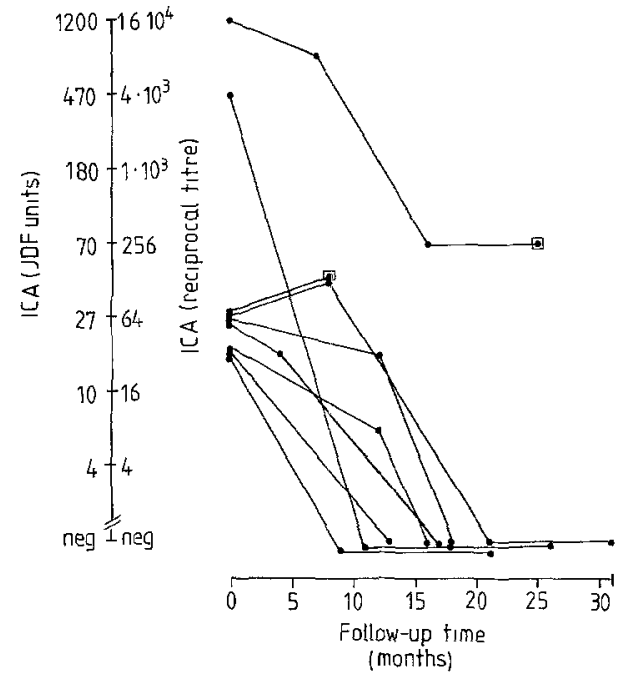

Fig.4. Levels of islet cell antibodies (ICA) in initial and follow-up samples from the nine control children found to be ICA positive. Three children were ICA negative in the second sample and four in the third sample. Two children indicated by squares developed Type 1 (insulin-dependent) diabetes mellitus during the time of observation

gation of a total population of incident cases of diabetic children was possible to carry out because Sweden has had a register of newly diagnosed Type 1 diabetic children since 1977 [6]. The population register gave us the unique opportunity to select non-related optimally matched control children. Despite the necessity of obtaining hospital control children from children younger than 7 years of age, our overall control group is clearly different from those in previous studies analysing ICA [39-49]. In addition, the new assays for thyroid peroxidase, thyroglobulin, and $\mathrm{H}^{+}, \mathrm{K}^{+}$.ATPase antibodies have recently becorne available [59] and have not previously been applied to sera from diabetic and control children.

Table 2. Characteristics of control children positive for islet cell antibodies (ICA)

\begin{tabular}{|c|c|c|c|c|c|c|}
\hline Child & $\begin{array}{l}\text { Age } \\
\text { (years) }\end{array}$ & Sex & $\begin{array}{l}\text { Heredity } \\
\text { of Type } 1 \\
\text { diabetes }\end{array}$ & $\begin{array}{l}\text { ICA level } \\
\text { (JDF Units) } \\
\text { initial and } \\
\text { follow-up }\end{array}$ & $\begin{array}{l}\text { Fasting C- } \\
\text { peptide } \\
(\mathrm{nmol} / 1)^{\mathrm{a}}\end{array}$ & $\begin{array}{l}\text { Time of } \\
\text { follow-up } \\
\text { (months) }\end{array}$ \\
\hline 1 & 13 & M & Adopted & 27,43, Neg, neg & $0.85,0.27,0.64$ & $8,21,31$ \\
\hline 2 & 10 & M & Father & $27,17, \mathrm{Neg}$ & $0.83,0.31$ & 12,18 \\
\hline $3^{b}$ & 9 & $\mathbf{F}$ & $\begin{array}{l}\text { Father, } \\
\text { cousin }\end{array}$ & $1200,760,70,70$ & $0.60,0.13,-$ & $7,16,25$ \\
\hline 4 & 11 & $\mathbf{F}$ & No & 470, Neg, neg, neg & $1.05,0.32,0.13$ & $11,18,26$ \\
\hline 5 & 11 & M & No & 17, Neg & 0.67 & 13 \\
\hline $6^{b}$ & 7 & M & No & 27,43 & - & 8 \\
\hline 7 & 9 & $\mathrm{~F}$ & No & 17, Neg, neg & $0.18,1.0$ & 9.22 \\
\hline $8^{c}$ & 11 & M & No & $17,6, \mathrm{Neg}$ & $0.60,0.20$ & 12,16 \\
\hline $9^{c}$ & 11 & M & Adopted & $27,17, \mathrm{Neg}$ & $0.48,0.28$ & 4. 17 \\
\hline
\end{tabular}

a The normal range of fasting $C$-peptide among children is $0.15-0.49 \mathrm{nmol} / 1$ [76]; b These children developed Type 1 (insulindependent) diabetes 8 and 25 months after the initial samples were obtained; ${ }^{c}$ Autoantibodies against other islet cells than proinsulin containing, probably glucagon producing A cells 
In this first case-control study of a total annual population of newly diagnosed diabetic children on a country-wide basis we establish that $81 \%$ of the patients are ICA positive, a frequency which is comparable to that in previous investigations [39-45]. The levels of ICA are difficult to compare since until now a standard has not been available $[56,60]$. Interestingly, the ICA negative patient group did not differ with respect to age, sex, geographical location, or frequency of other autoantibodies compared with the ICA positive patients. In a subsample of all patients $(40 / 389)$ we found antibodies against an $M_{r} 64,000$ islet protein in $73 \%(29 / 40)$ of the patients but in none of the control children $(0 / 40)$ [61]. Based on these results only about $13 \%$ would be negative for both ICA and $M_{r} 64,000$ antibodies. In contrast to an earlier study [44], but confirming a recent report [45], the frequency of ICA in the children with diabetes in this study did not vary with age, although the levels of ICA among the ICA positive patients tended to increase with age. The occurrence of childhood diabetes is equal in both sexes [50] and we found no difference in ICA frequency or levels between the sexes either. Previous epidemiological studies [6] have shown geographical variations in the incidence of diabetes in Sweden but a corresponding geographical variation in frequency or level of ICA among the diabetic children was not found in our study. In addition, the frequency and level of ICA were not influenced by the season of clinical onset, despite the seasonal variation of diabetes incidence $[6,11]$. Altogether, the uniformly distributed frequency and level of ICA in this complete population of newly diagnosed Type 1 diabetic children do not indicate any heterogeneity in the disease as claimed previously $[62,63]$.

The strong association between childhood Type 1 diabetes and HLA-DR 3 and/or $4[64,65]$ and even stronger to certain HLA-DQ alleles [66-68] and the low rate $(8 \%)$ of familial cases [50] made it important to establish a control population consisting of individuals not genetically related but otherwise carefully matched. The control children who were invited but refused to donate a serum sample were unlikely to influence the results since the purpose of the study was not disclosed. No preceding selection was done in the group of control children but no control child had diabetes at first sampling. It is noteworthy, in this respect, that none of our control children younger than 7 years of age, and selected by a paediatrician, were found to be ICA positive.

The results of the control group suggest that the frequency of ICA in the background population might be as high as 3\%. Most other studies have shown lower frequencies of ICA in control children [39-48], however, these children were not selected as matched control subjects to incident diabetic patients. Several investigators indicate that the frequency of ICA in the general population exceeds the prevalence of the disease itself [46-49], and in Finland with the highest known pre- valence, the ICA frequency was $4 \%$ [49]. The $3 \%$ carrier frequency of ICA among the control children in this study should therefore be compared with the prevalence of diabetes in this age group in Sweden which is $0.15 \%$ [6]. A low detection limit in the ICA assay and the risk of false positive results seems unlikely, since the frequency of ICA in the diabetic patients was not higher than in previous studies, and the positive control sera had levels where most assays certainly would find them positive.

If the ICA test could be used to screen an unselected population of Swedish children with the purpose of finding prediabetic subjects, the present study would allow us to calculate the predictive value of the ICA test. The sensitivity (all diseased individuals who had a positive test) was $81 \%$ and the specificity (all nondiabetic individuals who had a negative test) was $98 \%$. Since the prevalence of Type 1 diabetes is previously known to be $0.15 \%$, the predictive value of a positive ICA test (the proportion of ICA positive children who will have, or within the near future will develop Type 1 diabetes) would be only $5 \%$. Accordingly, the prevalence of ICA exceeds the prevalence of diabetes and ICA might, therefore, occur transiently without subsequent development of diabetes. In our study seven of initially nine ICA positive control children turned ICA negative without developing diabetes. Transiently occurring ICA has also previously been reported in children with mumps infection [69], in twins [70], as well as in Type 2 (non-insulin-dependent) patients [71].

Considering the $19 \%$ of the diabetic patients negative for ICA at diagnosis, these might have been recruited from subjects with previous transient ICA positivity. Anyhow, with this 3\% frequency of ICA among control children it is unlikely that the mere presence of ICA will indicate a later development of Type 1 diabetes. To better define the prognostic value of ICA in childhood further investigations of larger numbers of HLA-DQ-typed [68] control children are in progress. Based on studies of first degree relatives it has been argued that ICA is a marker of a later Type 1 diabetes [ 35 , $36,72]$. In our study, two of nine ICA positive control children developed diabetes 8 and 25 months after they entered as control children. Interestingly enough, one child had a father with Type 1 diabetes while the other had no family member with the disease (Table 2). The concordance of Type 1 diabetes among monozygotic twins is $25-50 \%[12,13]$ and in this and other studies [6, $50]$ only $8-12 \%$ of children with diabetes have a first degree relative with Type 1 diabetes. Since almost all previous studies on ICA in non-diabetic individuals have focused on highly selected family members, we must therefore conclude that little is known about the natural history of Type 1 diabetes in non-familial subjects.

Increased frequency of other organ-specific autoantibodies or diseases such as thyroiditis, pernicious anaemia, and primary adrenal insufficiency have been reported in Type 1 diabetic patients [3, 20-22]. The rea- 
son for the increased frequency is not understood but speculated to be due to a generally increased propensity to react strongly against certain antigens, or to a genetically poor ability to acquire tolerance to autoantigens, or perhaps to some common antigen shared in the tissues prone to autoimmune diseases [73-75]. In this study we have used novel and precise ELISA-tests to determine levels of TPO, TG, and gastic $\mathrm{H}^{+}, \mathrm{K}^{+}$-ATPase [59] antibodies. Our control children were used to define reference limits and apply these to the group of children with recent onset diabetes. In accordance with some [40, 73-75] but not all [42] studies we found significantly increased frequencies of these autoantibodies among the diabetic children. The girls were more often positive for TPO and TG antibodies than the boys, otherwise there was no association with age, sex, or geographical location for any of the autoantibodies. However, more important, only autoantibodies against TPO and TG showed a highly significant correlation but none of the other organ-specific autoantibodies were found to be associated with each other. In this study we could, therefore, not distinguish any subgroup of diabetic patients with several autoimmune antibodies. This could indicate, that diabetes in the 0-14 year age range develops independently of other organ-specific autoimmune disorders, also underlined by the observation that TPO and TG autoantibodies but not ICA occurred more frequently in girls. Our findings are, however, consistent with the hypothesis that an increased propensity to develop organ-specific autoantibodies is associated with an increased risk of developing Type 1 diabetes.

In conclusion, in this country-wide case-control study of childhood diabetes a high frequency (81\%), and high levels of ICA among children with recent onset of Type 1 diabetes were found. Neither levels nor frequency of ICA were associated with age at onset, sex, geographical location, season of onset, or presence of other organ-specific autoantibodies. The fact that the majority of cases with childhood diabetes occurs in children without first degree relatives with Type 1 diabetes and that the frequency of ICA in the control population was as high as $3 \%$ suggests that markers other than familial occurrence of Type 1 diabetes and ICA will be necessary in the prediction of diabetes.

Acknowledgements. This study was supported by grants from the Swedish Medical Research Council (project no 19X-07507, 07531, 04996), the Swedish Diabetes Association, the National Institutes of Health (DK26190, DK33873), the Juvenile Diabetes Foundation International, the Malmö Diabetes Association, the Lundström Foundation, the University Foundation, and the Malmö General Hospital Foundation. We are indepted to B.Delgado-Frohm, C.Johansson, K. Bjelkenkrantz, and M.Olsson for skilful technical assistance, B. Völer for help in preparing the manuscript, and H.Olsson for statistical advice. Dr. S.Mårdh, Uppsala, generously provided the antigen for the $\mathrm{H}^{+}, \mathrm{K}^{+}$-ATPase antibody analyses. We also acknowlege, with thanks, the assistance of the following co-workers: $\mathrm{L}$. Nyström, A.Sandström, S.Wall, Department of Epidemiology and Health Care Research, University of Umeå; and from all Depart- ments of Pediatrics in Sweden, M.Aili, Halmstad; H.Bäckman, Gävle; E.Carlsson, Kalmar; H.Edenwall, Karlskrona; P-O.Elfstrand, Skövde; B.W.Granström, Gällivare; I. Gustavsson, Skellefteå; L-E. Gustavsson, Östersund; A. Hallberg, Landskrona; B. Hansing, Lidköping; R.Hanås, Uddevalla; L. Hellenberg, Nyköping; E.Holmberg, Umeå; H.Hörnell, Hudiksvall; G.Jonsell, Karlstad; C.Jönsson, Sollefteå; K.Kockum, Ystad; U.Lindberg, Växjö; B. Lindblad, Mölndal; J. Ludvigsson, Linköping; V. Mazreliez, Visby; U.Myrdal, Västerås; J.Neiderud, Helsingborg; K-O.Nilsson, Malmö; B.Persson, Stockholm; P.G.Petzén, Västervik; G. Samuelsson, Vänersborg; K.Segnestam, Eskilstuna; N.Sigurs, Borås; S.Sjöblad, Lund; S.Sjögren, Örnsköldsvik; L.Skogsberg, Boden; T.Smith, Kristianstad; K. Snellman, Falun: L. Strömberg, Norrköping; U.Ståle, Ängelholm; J.Tenstam, Sundsvall; B.Thalme, Huddinge; A.Thilén, Jönköping; K. Tullus, Danderyd; T. Tuvemo, Uppsala; O. Westphal, Göteborg; and J. Åman, Örebro.

\section{References}

1. Diabetes Mellitus (1985) Report of a WHO Study Group. World Health Organization Technical Report Series. World Health Organization, Geneva No. 727: 7-13

2. Cahill GF, McDevitt HO (1981) Insulin-dependent diabetes mellitus: the initial lesion. N Engl J Med 304: 1454-1465

3. Hamman RF, Berlin N (1985) International workshop on the epidemiology of insulin-dependent diabetes mellitus. Diabetes Care 8 [Suppl 1]: 1-109

4. Borch-Johnsen K, Kreiner S, Deckert T (1986) Mortality of Type 1 (insulin-dependent) diabetes mellitus in Denmark: a study of relative mortality in 2930 Danish Type 1 diabetic patients diagnosed from 1933 to 1972. Diabetologia 29: 767-772

5. Dorman JS, Tajima N, LaPorte RE, Becker DJ, Cruickshanks KJ, Wagener DK, Orchard TJ, Drash AL (1985) The Pittsburgh insulin-dependent diabetes mellitus (IDDM) morbidity and mortality study: case-control analyses of risk factors for mortality study: case-control analyses of risk factors for mortality. Diabetes Care 8 [Suppl 1]: $54-60$

6. Dahlquist G, Blom L, Holmgren G, Hägglöf B, Larsson Y, Sterky G, Wall S (1985) The epidemiology of diabetes in Swedish children 0-14 years - A sex-year prospective study. Diabetologia 28: 802-808

7. Ákerblom HK, Reunanen A (1985) The epidemiology of insulindependent diabetes mellitus (IDDM), in Finland and in Northern Europe. Diabetes Care 8 [Suppl 1]: 10-16

8. Patterson CC, Thorogood M, Smith PG, Heasman MA, Clarke JA, Mann JI (1983) Epidemiology of type 1 (insulin-dependent) diabetes in Scotland 1968-1976; evidence of an increasing incidence. Diabetologia 24: $238-243$

9. Palumbo P, LaBarthe D (1978) The incidence of diabetes mellitus in Rochester, Minnesota, 1945-1969. Adv Metab Disord 9: 13-28

10. Adams SF (1926) The seasonal variation in the onset of acute diabetes. Arch Intern Med 37: 861-864

11. Gamble DR, Taylor KW (1969) Seasonal incidence of diabetes mellitus. Br Med J 3: 631-633

12. Tattersall RB, Pyke DA (1972) Diabetes in identical twins. Lancet II: $1120-1125$

13. Barnett AH, Eff C, Leslie RDG, Pyke DA (1981) Diabetes in identical twins. Diabetologia 20:87-93

14. Gamble DR (1977) Viruses and diabetes: an overview with special reference to epidemiological studies. In: Bajaj JS (ed) Proceedings of the IX congress of the International Diabetes Federation. Excerpta Medica, Amsterdam, Oxford pp 285-293

15. Yoon JW, Austin M, Onodera T, Notkins AL (1979) Virus-induced diabetes mellitus. N Engl $J$ Med 300: 1173-1179

16. Ginsberg-Fellner F, Witt ME, Yagihashi S, Dobersen MJ, Taub F, Fedun B, McEvoy RC, Roman SH, Davies TF, Cooper LZ, Rubinstein P, Notkins AL (1984) Congenital rubella syndrome as a model for Type 1 (insulin-dependent) diabetes mellitus: increased prevalence of islet cell surface antibodies. Diabetologia 27: 87-89 
17. Rayfield EJ, Seto Y (1978) Viruses and the pathogenesis of diabetes mellitus. Diabetes 27: 1126-1140

18. Helgason T, Jonasson MR (1981) Evidence for a food additive as a cause of ketosis-prone diabetes. Lancet II: 716-720

19. Karam JH, Lewitt PA, Young CW, Nowlain RE, Frankel BJ, Fujiya H, Freedman ZR, Grodsky GM (1980) Insulinopenic diabetes after rodenticide (Vacor) ingestion. A unique model of acquired diabetes in man. Diabetes 29: 971-978

20. Powers AC, Eisenbarth GS (1985) Autoimmunity to islet cells in diabetes mellitus. Ann Rev Med 36: 533-544

21. Drell DW, Notkins AL (1987) Multiple immunological abnormalities in patients with Type 1 (insulin-dependent) diabetes mellitus. Diabetologia 30: 132-143

22. Lernmark $\AA$, Li S, Baekkeskov S, Christie M, Michelsen B, Ursing J, Landin-Olsson M, Sundkvist G (1987) Islet-specific immune mechanisms. Diabetes Metab Rev 3: 959-980

23. Gepts W (1965) Pathologic anatomy of the pancreas in juvenile diabetes mellitus. Diabetes 14: 619-633

24. Foulis AK, Stewart JA (1984) The pancreas in recent-onset Type 1 (insulin-dependent) diabetes mellitus: insulin content of islets, insulitis and associated changes in the exocrine acinar tissue. Diabetologia $26: 456-461$

25. Bottazzo GF, Dean BM, McNally JM, MacKay EH, Swift PGF, Gamble DR (1985) In situ characterization of autoimmune phenomena and expression of HLA molecules in the pancreas in diabetic insulitis. N Engl J Med 313: 353-360

26. Rahier J, Goebbels RM, Henquin JC (1983) Cellular composition of the human diabetic pancreas. Diabetologia 24: 366-371

27. Bottazzo GF, Florin-Christensen A, Doniach D (1974) Islet cell antibodies in diabetes mellitus with autoimmune polyendocrine deficiencies. Lancet II: 1279-1283

28. MacCuish AC, Barnes EW, Irvine WJ, Duncan LJP (1974) Antibodies to pancreatic islet-cells in insulin-dependent diabetics with coexistent autoimmune disease. Lancet II: 1529-1531

29. Lernmark $\AA$, Freedman ZR, Hofmann C, Rubenstein AH, Steiner DF, Jackson RL, Winter RJ, Traisman HS (1978) Islet-cell-surface antibodies in juvenile diabetes mellitus. N Engl J Med 299: $375-380$

30. Dobersen MJ, Scharff JE, Ginsberg-Fellner F, Notkins AL (1980) Cytotoxic autoantibodies to beta-cells in the serum of patients with insulin-dependent diabetes mellitus. N Engl J Med 303: 1493-1498

31. Eisenbarth GS, Morris MA, Scearce RM (1981) Cytotoxic antibodies to cloned rat islet cells in serum of patients with diabetes mellitus. J Clin Invest 67: 403-408

32. Baekkeskov S, Nielsen JH, Marner B, Bilde T, Ludvigsson J, Lernmark $\AA$ (1982) Autoantibodies in newly diagnosed diabetic children immunoprecipitate human pancreatic islet cell proteins. Nature 298: 167-169

33. Baekkeskov S, Landin M, Kristensen JK, Srikanta S, Bruining GJ, Mandrup-Poulsen T, de Beaufort C, Soeldner JS, Eisenbarth G, Lindgren F, Sundkvist G, Lernmark A (1987) Antibodies to a $M_{r} 64,000$ human islet cell antigen precede the clinical onset of insulin dependent diabetes. $J$ Clin Invest 79: 926-934

34. Palmer JP, Asplin CM, Clemons P, Lyen K, Tatpati O, Raghu PK, Paquette TL (1983) Insulin antibodies in insulin-dependent diabetics before insulin treatment. Science 222: 1337-1339

35. Gorsuch AN, Spencer KM, Lister J, McNally JM, Dean BM, Bottazzo GF, Cudworth AG (1981) Evidence for a long prediabetic period in Type 1 (insulin-dependent) diabetes mellitus. Lancet II: 1363-1365

36. Srikanta S, Ganda OP, Rabizadeh A, Soeldner JS, Eisenbarth GS (1985) First-degree relatives of patients with Type I diabetes mellitus. Islet-cell antibodies and abnormal insulin secretion. $\mathbf{N}$ Engl $\mathbf{J}$ Med 313: 462-464

37. MacCuish AC, Irvine WJ (1975) Autoimmunological aspects of diabetes mellitus. Clin Endocrinol Metab 4: 435-471

38. Bottazzo GF, Cudworth AG, Moul DJ, Doniach D, Festenstein H (1978) Evidence for a primary autoimmune type of diabetes mellitus. Br Med J 2: 1253-1255
39. Lendrum R, Walker G, Gamble DR (1975) Islet-cell antibodies in juvenile diabetes mellitus of recent onset. Lancet $\mathrm{I}: 880-883$

40. Irvine WJ, McCallum CJ, Gray RS, Campbell CJ, Duncan LJP, Farquhar JW, Vaughan H, Morris PJ (1977) Pancreatic islet cell antibodies in diabetes mellitus correlated with the duration and type of diabetes, coexistent autoimmune disease, and HLA-type. Diabetes 26: 138-147

41. Del Prete GF, Betterle C, Padovan D, Erle G, Toffolo A, Borsahi $\mathrm{G}$ (1977) Incidence and significance of islet-cell auto-antibodies in different types of diabetes mellitus. Diabetes 26:909-915

42. Lernmark Å, Hägglöf $B$, Freedman Z, Irvine J, Ludvigsson J, Holmgren G (1981) A prospective analysis of antibodies reacting with pancreatic islet cells in insulin-dependent diabetic children. Diabetologia 20: $471-474$

43. Bottazzo GF, Dean BM, Gorsuch AN, Cudworth AG, Doniach D (1980) Complement-fixing islet-cell antibodies in type 1 diabetes: possible monitors of active beta-cell damage. Lancet I: 668-672

44. Helmke K, Otten A, Mäser E, Wolf H, Federlin K (1987) Islet cell antibodies, circulating immune complexes and antinuclear antibodies in diabetes mellitus. Horm Metab Res 19: 312-315

45. Kolb H, Dannehl K, Grüneklee D, Zielasek J, Bertrams J, Hübinger A, Gries FA (1988) Prospective analysis of islet cell antibodies in children with Type 1 (insulin-dependent) diabetes. Diabetologia 31: 189-194

46. Maclaren NK, Horne G, Spillar RP, Barbour H, Harrison D, Duncan J (1985) Islet cell antibodies (ICA) in U.S. school children. Diabetes 34 [Suppl 1]: 84 (Abstract)

47. Bergua M, Solé J, Marion G, Perez MC, Recasens A, Fernandez J, Casamitjana R, Gomis R (1987) Prevalence of islet cell antibodies, insulin antibodies and hyperglycaemia in 2291 schoolchildren. Diabetologia 30: 724-726

48. Bruining GJ, Molenaar JL, Grobbee DE, Hofman A (1988) A 10 year retrospective follow-up of islet cell antibody positivity in children of a township in Holland. Diabetologia 31: 474 (Abstract)

49. Karjalainen $J$ (1988) Prevalence of cytoplasmic islet cell antibodies in a Finnish 3-18 year-old general population - a crosssectional study of 1206 subjects. Diab Res Clin Pract 5 [Suppl 1]: 254 (Abstract)

50. Dahlquist G, Blom L, Tuvemo T, Nyström L, Sandström A, Wall S (1989) The Swedish childhood diabetes study - Results from a nine year case register and one year case-referent study indicating that Type 1 (insulin-dependent) diabetes mellitus is associated with both Type 2 (non-insulin-dependent) diabetes mellitus and autoimmune disorders. Diabetologia 32:2-6

51. Heding LG (1975) Radioimmunological determination of C-peptide in serum. Diabetologia 11: 541-548

52. Madsen OD, Landin-Olsson M, Bille G, Sundkvist G, Lernmark $\AA$, Dahlqvist G, Ludvigsson J (1986) A two-colour immunofluorescence test with a monoclonal human proinsulin antibody improves the assay for islet cell antibodies. Diabetologia 29: $115-118$

53. Landin-Olsson M, Sundkvist G, Lernmark $\AA$ (1987) Prolonged incubation on the two-colour immunofluorescent test increases the prevalence and titres of islet cell antibodies in Type 1 (insulin-dependent) diabetes mellitus. Diabetologia 30:327-332

54. Madsen OD, Cohen RM, Fitch FW, Rubenstein AH, Steiner DF (1983) The production and characterization of monoclonal antibodies specific for human proinsulin using a sensitive microdot assay procedure. Endocrinol 113: 2135-2144

55. Pilcher C, Elliot RB (1984) Improved sensitivity of islet cell cytoplasmic antibody assays in diabetics. Lancet I: 1352

56. Bonifacio E, Lernmark $\AA$, Dawkins RL (1988) Serum exchange and use of dilutions have improved precision of measurement of islet cell antibodies. J Immunol Methods 106: 83-88

57. Gustavsson J, Mendel-Hartvig I, Tötterman TH, Karlsson FA (1987) Purification of human thyroid peroxidase using ion exchange liquid chromatography. J Clin Lab Immunol 23: 57-61

58. Karlsson FA, Burman P, Lööf L, Mårdh S (1988) Major parietal cell antigen in autoimmune gastritis with pernicious anemia is the 
acid-producing $\mathrm{H}^{+}, \mathrm{K}^{+}$-adenosin triphosphatase of the stomach. J Clin Invest $81: 475-479$

59. Karlsson FA, Burman P, Lööf L, Olsson M, Scheynius A, Mårdh $\mathrm{S}$ (1987) Enzyme linked immunosorbent assay of $\mathrm{H}^{+}, \mathrm{K}^{+}$-ATPase, the parietal cell antigen. Clin Exp Immunol 70: 604-610

60. Bottazzo GF, Gleichman H (1986) Workshop report. Immunology and diabetes workshops: report of the first international workshop on the standardisation of cytoplasmic islet cell antibodies. Diabetologia 29: 125-126

61. Christie M, Landin-Olsson M, Sundkvist G, Dahlquist G, Lernmark $\AA$, Bækkeskov $S$ (1988) Antibodies to a $M_{r} 64,000$ islet cell protein in Swedish children with newly diagnosed Type 1 (insulindependent) diabetes. Diabetologia 31: 597-602

62. Rotter JI, Rimoin DL (1978) Heterogeneity in diabetes mellitusupdate. Diabetes 27: 599-608

63. Rotter JI, Rimoin DL (1981) The genetics of the glucose intolerance disorders. Am J Med 70: 116-126

64. Wolf E, Spencer KM, Cudworth AG (1983) The genetic susceptibility to Type 1 (insulin-dependent) diabetes: analysis of the HLADR association. Diabetologia 24: 224-230

65. Platz P, Jakobsen BK, Morling M, Ryder LP, Svejgaard A, Thomsen M, Christy M, Kromann H, Benn J, Nerup J, Green A, Hauge M (1981) HLA-D and DR-antigens in genetic analysis of insulindependent diabetes mellitus. Diabetologia 21: 108-115

66. Owerbach D, Lernmark $\AA$, Platz P. Ryder LP, Rask L, Peterson PA, Ludvigsson J (1983) HLA-D region $\beta$-chain DNA endonuclease fragments differ between HLA-DR identical healthy and insulin-dependent diabetic individuals. Nature 303: 815-817

67. Nepom BS, Palmer J, Kim SJ, Hansen JA, Holbeck SL, Nepom GT (1986) Specific genomic markers for the HLA-DQ subregion discriminate between DR4 ${ }^{+}$insulin-dependent diabetes mellitus and DR4 ${ }^{+}$seropositive juvenile rheumatoid arthritis. J Exp Med 164: $345-350$

68. Michelsen B, Lernmark Å (1987) Molecular cloning of a polymorphic DNA endonuclease fragment associates insulin-dependent diabetes mellitus with HLA-DQ. J Clin Invest 79: 1144-1152

69. Helmke K, Otten A, Willems WR, Brockhaus R, Mueller-Eckhardt G, Stief T, Bertrams J, Wolf $H$, Federlin K (1986) Islet cell antibodies and the development of diabetes mellitus in relation to mumps infection and mumps vaccination. Diabetologia 29:30-33

70. Millward BA, Alviggi L, Hoskins PJ, Johnston C, Heaton D, Bottazzo GF, Vergani D, Leslie RD, Pyke DA (1986) Immune changes associated with insulin-dependent diabetes may remit without causing the disease, a study in identical twins. Br Med J 292: 793-796

71. Kobayashi T, Itoh T, Kosaka K, Sato K, Tsuji K (1987) Time course of islet cell antibodies and $\beta$-cell function in non-insulindependent stage of Type 1 diabetes. Diabetes 36: 510-517

72. Tarn AC, Thomas JN, Dean BM, Ingram D, Schwarz G, Bottazzo GF, Gale EAM (1988) Predicting insulin-dependent diabetes. Lancet I: $845-850$

73. Vialkow PJ, Zavala C, Nielsen R (1975) Thyroid autoimmunity: Increased frequency in relatives of insulin-dependent diabetes patients. Ann Int Med 83: 170-176

74. Maclaren NK, Riley WJ (1985) Thyroid, gastric, and adrenal autoimmunities associated with insulin-dependent diabetes mellitus. Diabetes Care 8 [Suppl 1]: 34-38

75. Nordén G, Jensen E, Stilbo I, Bottazzo GF, Lernmark Å (1983) Bcell function and islet cell and other organ-specific autoantibodies in relatives to insulin-dependent diabetic patients. Acta Med Scand 213: 199-203

76. Ivarsson SA, Johansson E, Nilsson KO, Thorell JI (1987) Urinary C-peptide excretion at onset of insulin-dependent diabetes mellitus in children. Acta Paediatr Scand 76: 608-611

Received: 15 December 1988

and in revised form: 31 March 1989

Dr. M.Landin-Olsson

Department of Medicine

University of Lund

Malmö General Hospital

S-214 01 Malmö

Sweden 